\title{
Compte rendu de la série Redfern Now, par Rachel
} Perkins et al.

\section{Vanessa Castejon}

\section{OpenEdition}

1 Journals

Édition électronique

URL : https://journals.openedition.org/jso/10423

DOI : $10.4000 /$ jso. 10423

ISSN : 1760-7256

\section{Éditeur}

Société des océanistes

\section{Édition imprimée}

Date de publication : 15 juillet 2019

Pagination : 171-173

ISBN : 978-2-85430-137-3

ISSN : 0300-953x

\section{Référence électronique}

Vanessa Castejon, «Compte rendu de la série Redfern Now, par Rachel Perkins et al. », Journal de la Société des Océanistes [En ligne], 148 | 2019, mis en ligne le 15 juillet 2019, consulté le 22 juillet 2021. URL : http://journals.openedition.org/jso/10423 ; DOI : https://doi.org/10.4000/jso.10423

\section{cc)}

Journal de la société des océanistes est mis à disposition selon les termes de la Licence Creative Commons Attribution - Pas d'Utilisation Commerciale - Pas de Modification 4.0 International. 


\section{COMPTES RENDUS}

PERKINs Rachel et al., 2012-2015. Redfern Now, série composée de 2 saisons de 6 épisodes $(52 \mathrm{~min}$ ) chacune, Australie, Blackfella Films.

Cette série télévisée australienne, aborigène, est étonnante à plusieurs titres : elle est "from somewhere unseen " disent les réalisateurs et les acteurs, elle est une lucarne atypique sur la communauté, le quartier, une perspective rare sur les questions autochtones. C'était la volonté des réalisateurs et des commanditaires et cela est réussi.

Redfern Now est la première série à être commandée (par la chaîne $\mathrm{ABC}$ et produite par Blackfella Films), réalisée (Rachel Perkins, Catriona McKenzie, Wayne Blair et Leah Purcell) et jouée par des Aborigènes et Insulaires du Détroit de Torres (Rourke, 2012). La série est constituée de deux saisons de six épisodes et un téléfilm, elle a été diffusée sur $\mathrm{ABCl}$ en Australie entre 2012 et 2015 et a reçu de nombreuses récompenses (en France, seul le téléfilm final a été montré par la chaîne Arte ; au Royaume Uni, elle a été disponible sur les plateformes de streaming payantes). Elle se déroule dans le "quartier aborigène" de Sydney, Redfern. Son titre annonce son contenu : il s'agit s'une série qui concerne les Aborigènes urbains d'aujourd'hui, et plus particulièrement ceux de ce quartier. Chaque épisode, non lié aux autres, se focalise sur des hommes et des femmes face à un bouleversement survenu dans leur vie quotidienne. La construction narrative reste assez simple : le personnage rencontre un problème - c'est la perturbation initiale - qu'il cherche ensuite à résoudre.

Certains déplorent que la série laisse penser qu'elle représenterait "les Aborigènes ", qu'elle laisse entendre qu'elle est la voix du quartier entier, qu'elle serait représentative. Une autre remarque est qu'elle dit représenter Redfern "Now ", maintenant, mais le quartier porte son histoire et la série, réalisée en
2012-2015, porte également l'histoire du lieu et de ses habitants. L'universitaire/militant Gary Foley, personnage clef de l'histoire politique du lieu, décrit Redfern comme la plus grosse communauté aborigène d'Australie (Tan, 2016). Redfern a été le berceau des contestations politiques autochtones à commencer par les Freedom Rides dans les années 60 qui y sont nées: un groupe, principalement composé d'étudiants de l'université de Sidney, mené par l'activiste aborigène Charles Perkins, a sillonné les routes de Nouvelle-Galles du Sud en bus pour dénoncer le racisme. Une des réalisatrices de Redfern Now est d'ailleurs la fille de Charles Perkins. Le quartier a vu naitre le Black Power en 1968/1972 (Foley, 2001) dont les membres ont également créé le Redfern Aboriginal Legal service en 1970. Nombre de militants de la « tente ambassade » aborigène en 1973, qui ont installé une ambassade aborigène sur les pelouses $\mathrm{du}$ Parlement fédéral pour revendiquer droits fonciers et droits politiques, venaient également de ce quartier. Redfern est aussi le lieu où le premier ministre Paul Keating ${ }^{1}$ a délivré un des discours les plus célèbres en matière de relations entre Aborigènes et non Aborigènes, en 1993 (Keating, 2012), qui marque le début d'une reconnaissance des maux infligés par la colonisation et qui a mené au « Sorry » du premier ministre Kevin Rudd en 2008, après quinze années de politique dite de "réconciliation ". Redfern a également été le centre de l'attention médiatique pendant les jeux olympiques de Sydney en 2000 avec l'installation d'une "tente ambassade" provisoire comme vitrine des revendications pour un traité pour la souveraineté aborigène. Le quartier a aussi été fortement médiatisé pendant les émeutes de 2004 après la mort d'un jeune homme pourchassé par la police. L'image de Redfern est liée à une histoire de conflits et de revendications : "C'est un endroit intimidant " dit l'acteur autochtone (insulaire du détroit de Torres) Jimi Bani.

"Quand vous êtes à Cairns et que vous entendez le mot "Redfern", vous pensez "grabuge". " (Elliott, 2012)

1. Extrait du Redfern Speech de Paul Keating : «it begins I think with an act of recognition: recognition that it was we who did the dispossessing, we took the traditional lands and smashed the traditional way of life, we brought the diseases and the alcohol, we committed the murders, we took the children from their mothers, we practiced discrimination and exclusion, it was our ignorance and our prejudice. " 
Il est impossible de parler de la série sans parler longuement du quartier, en pleine mutation. Redfern a longtemps été un quartier pauvre. D'après Gary Foley, dans les années 70, ce qui liait les gens de Redfern était la pauvreté (Tan, 2016). Il est intéressant de voir que ce qui unit le quartier,consiste en l'appartenance à une communauté mais aussi, simplement, à une classe sociale. Redfern a commencé à changer sur cet aspect dans les années qui ont précédé la série (surtout depuis 2009, cf. Booth, 2015), le quartier est maintenant en pleine gentrification (Farrelly, 2017 ; Ikin, 2014 ; Zhou, 2017 ; Young, 2016). Certains habitants parlent d'éradication, de dépossession (Farrelly, 2017). La série est donc sortie à un moment où les habitants se sentaient dépossédés. Les commentaires des journalistes sur la série évoquent ethnicité et contexte socio-économique et comparent la série aux premières œuvres de Spike Lee (Buckmaster, 2015).

Redfern Now dépeint le quotidien du quartier et évoque aussi la violence domestique, la parenté, l'homosexualité, la réussite sociale, l'addiction, le stress post-traumatique lié à la guerre, le viol, les préjugés, les questions identitaires (" qu' est-ce qu'être "noir" ?" dans l'épisode Stand Up, saison 1 épisode 4), la place des femmes, entre autres. On pourrait évoquer les personnages de femmes, très forts : Grace, Lorraine, Robyn, Coral, Teneka, évoquer aussi Aaron, le policier qui est le lien entre plusieurs épisodes, également amoureux attendrissant, ou encore Joel Shields qui refuse de chanter l'hymne australien à l'école. Ce dernier est joué par Aaron McGrath, jeune de Redfern embauché dans la série, très remarqué, et qui continue sa carrière d'acteur depuis. On pourrait faire une galerie des personnages mais le personnage principal est Redfern comme New York a pu être le personnage principal de plusieurs séries américaines. Les personnages sont censés être "normaux». Un des réalisateurs compare Redfern Now à la série australienne $\mathrm{La}$ Gifle, dans le sens où il n'y aurait pas de stéréotypes, juste des gens ordinaires (Elliott, 2012). La série est centrée autour du "Block ", dans le voisinage de la gare de Redfern, autour de quelques foyers dont les histoires se chevauchent ( $\mathrm{ABC} 1 \mathrm{TV}, 2013 \mathrm{~b}$ ).

En 1993, l'universitaire/militante aborigène Marcia Langton dénonçait le nombre de film faits «sur » les Aborigènes. Ici, ce sont bien les points de vue aborigènes qui sont entendus, il s'agit d'une vue " de l'intérieur " et c'est ce qui fait l'originalité de la série. Elle donne de la visibilité au quartier, à la communauté aussi, suivant le souhait de la chaîne ABC. En effet, Sally Riley, réalisatrice et écrivaine et directrice du service autochtone de la chaîne $\mathrm{ABC}$, a été recrutée pour travailler à l'augmentation des contenus autochtones sur la chaîne (Rourke, 2012). Son idée est que, pour une fois, la vision n'est pas imposée (sur l'invisibilité, on pourrait évoquer le "Great Australian Silence " mentionné par W. Stanner en 1968 et le débat sur les « History wars »). S. Riley semble avoir rempli sa mission puisque certains spectateurs lui disent qu'ils ignoraient que ce monde existait (ibid.). Une actrice de la série parle de la curiosité éveillée par ce type de communauté (ABC1 TV, 2013a).

La série propose un regard nouveau mais il s'agit donc d'une commande financée par le service public, ABC, dotée d'un budget de cinq millions de dollars par an (Rourke, 2012). Tant de moyens ont-ils été engagés pour apporter une autre perspective, pour apporter de la visibilité ? Cela a-t-il fonctionné ? Comment la série a-t-elle été accueillie ? En Australie, ABC est une chaîne publique et ce n'est pas la chaîne la plus regardée (chaque épisode a été vu en moyenne par environ 500 à 600000 Australiens, cf. https:// en.wikipedia.org/wiki/Redfern_Now\#Series_1). La réception autochtone a été nuancée et le manque de représentativité de Redfern, comme on l'a mentionné, a été souligné (Collins, 2013). La critique a encensé la série, seuls les cercles ultra-conservateurs l'ont mal accueillie. Les détracteurs aux droits aborigènes s'y sont intéressés et ont dénoncé le gaspillage de l'argent de l'État pour donner un point de vue qui leur semble biaisé. Ils ont évoqué une victimisation (O'Brian, 2016) mais aussi un "doigt d'honneur " aux australiens non-aborigènes. D'autres mentionnent une propagande gauchiste (Martin, 2016) et même un lavage de cerveau (Demandsel, 2016).

Redfern Now est perçue, positivement ou non, comme une entreprise de réappropriation culturelle, mais la réception à l'étranger peut apporter une autre perception, qui rendrait la question de ces marges transculturelles. En effet, on peut s'intéresser à la façon dont cette série a été perçue en France et, plus particulièrement, à la manière dont d'autres "marges " la reçoivent. Pourquoi ? Chacun regarde avec sa propre histoire, l'histoire de son pays. Ayant écrit mon "Ego-histoire " (Castejon, 2010) d'après la méthode initiée par Pierre Nora en 1987, ayant fait écrire leur propre histoire à des historiens travaillant sur les questions autochtones australiennes (Castejon et al., 2014), j'ai choisi de demander à mes étudiants venant de quartiers dits "difficiles » comment ils percevaient la série. Venant moi-même de ces quartiers et ayant travaillé sur les liens entre mon histoire et ma recherche, il me semblait que ce lien pan-marginalia était évident. Entre 2013 et 2017, j’ai donc montré deux épisodes (les n ${ }^{\text {os }} 2$ et 4 de la saison 1, $c f . \mathrm{ABC} 1 \mathrm{TV}, 2012)$ de la série à mes étudiants en DUT de Génie industriel et maintenance à l'IuT de Saint-Denis. Ils ont été insensibles aux particularités autochtones australiennes, à l'histoire du pays qu'ils ne connaissaient pas. Ils ne comprenaient pas, par exemple, pourquoi une femme blanche, disaient-ils, se revendiquait aborigène (épisode 2, saison 1 ). Ils ne voyaient pas ce qui était propre à l'aboriginalité mais créaient une identité commune: ils s'identifiaient entièrement aux personnages, mentionnaient (entre autres) un sens identique du partage dans le quartier, les mêmes tentations, le même racisme. Certains se sont identifiés au jeune homme qui a du mal à accepter de chanter l'hymne australien, qui se bat avec les définitions imposées de l'aboriginalité et de l'australianité. Mes étudiants ont associé la marginalisation 
des deux pays et créé une passerelle. La souveraineté culturelle comme les revendications identitaires peuvent donc faire écho ailleurs et participer à une forme de reconnaissance.

La culture dominante avait effacé ces voix du petit écran. Elles apparaissent grâce à cette série et cette vision décolonisée irradie jusqu'en France...

\section{RÉFÉRENCES CITÉES \\ (tous les sites Internet ont été consultés pour la dernière fois le 31/08/2018)}

ABCI TV, 2012. Redfern Now: Trailer de la saison 1, vidéo, $1 \mathrm{~min}$ (https://www.youtube.com/ watch?v=K2DpbsKbnPU).

-, 2013a. Redfern Now: About the community, vidéo, 2 min $36 \mathrm{sec}$ (https://www.youtube.com/ watch?v=jenEmAJ8qB4);

—, 2013b. Redfern Now : About the creators, vidéo, $2 \mathrm{~min} 15 \mathrm{sec}$ (https://www.youtube.com/ watch? $v=z R L Q e w 19 E 4 E)$.

Воотн Andrea, 2015 (24/02-11/03). Explainer: Redfern Aboriginal Tent Embassy and Aboriginal Housing Company dispute, NITV News (https://www. sbs.com.au/nitv/nitv-news/article/2015/02/24/ explainer-redfern-aboriginal-tent-embassy-andaboriginal-housing-company-dispute).

BUCKMASTER Luke, 2015 (9/04). Redfern Now: Promise Me review - final, unsettling showing from a superb cast, The Guardian (https://www. theguardian.com/tv-and-radio/2015/apr/10/ redfern-now-promise-me-review-final-unsettlingshowing-from-a-superb-cast).

Castejon Vanessa, 2010. Identity and Identification: Aboriginality from the Spanish Civil War to the French Ghettos, in F. Peters-Little, A. Curthoys and J. Docker (eds), Passionate Histories: Myth, Memory and Indigenous Australia, Acton, ANU e-press, coll. Aboriginal History Journal, pp. 219-228.

Castejon Vanessa, Anna Cole, Oliver Haag and Karen Hughes (eds), 2014. Ngapartji Ngapartji In turn, in turn, Ego-Histoire, Europe And Indigenous Australia, Canberra, ANU Press.

Coluns Felicity, 2013. Blackfella Films: decolonizing urban Aboriginality in Redfern Now, Studies in Australasian Cinema journal 7 (2-3), pp. 215-225.

Demandsel, 2016 (3/03, 5H26). Commentaire "Thank you Peter...", Quadrant online (https://quadrant.org.au/opinion/bennelong-papers/2016/03/stand-whine/\#comment-13737).

ELLiotT Tim, 2012 (25 oct.). Redfern in their words, The Sydney Morning Herald (https://www.smh. com.au/entertainment/tv-and-radio/redfern-intheir-words-20121024-284jf.html).

FARrelly Elizabeth, 2017 (28/04). The Redfern I loved has changed beyond recognition, The Sydney Morning Herald (http://www.smh.com.au/comment/the-redfern-i-loved-has-changed-beyondrecognition-20170427-gvu09y.html).
Foley Gary, 2001 (5/10). Black Power in Redfern 1968-1972, The Koori History Website [Aboriginal History of South Eastern Australia] (http://www. kooriweb.org/foley/essays/essay_1.html).

IkIN Sam, 2014 (3/02). There Goes The Block: The Gentrification of Redfern, World News Australia, vidéo de $3 \mathrm{~min} 52 \mathrm{sec}$ (https://www.youtube. $\mathrm{com} /$ watch?v=z-uo4X8JU3E).

Keating Paul, 2012. Redfern Speech, Australie, National Archives of Australia, vidéo, $16 \mathrm{~min}$ $49 \mathrm{sec}$ (https://www.youtube.com/watch?v=x1S 4F1euzTw).

Langton Marcia, 1993. "Well, I heard it on the radio and i saw it on the television": an essay for the Australian Film Commission on the politics and aesthetics of filmmaking by and about Aboriginal people and things, North Sydney, Australian Film Commission.

Martin Bill, 2016 (3/03, 2h49). Commentaire "I also remember that...", Quadrant online (https://quadrant.org.au/opinion/bennelong-papers/2016/03/stand-whine/\#comment-13731).

O’Brian Peter, 2016 (3/03). 'Stand Up' and Whine, Quadrant online (https:/quadrant.org.au/opinion/bennelong-papers/2016/03/stand-whine/).

Rourke Alison, 2012 (1/11). Australian TV drama puts spotlight on Aboriginal life, The Guardian (https://www.theguardian.com/world/2012/ nov/01/australian-drama-aboriginal-redfernnow).

Stanner William E.H., 1974 [1968]. After the Dreaming: black and white Australians - an anthropologist's view, Sydney, The Australian Broadcasting Commission.

TAN Monica, 2016 (11/05). The Aboriginal Tent Embassy: 'We were all young, crazy, but we believed in justice', The Guardian (https://www. theguardian.com/australia-news/2016/may/11/ gary-foley-and-the-aboriginal-tent-embassy-wewere-all-young-crazy-but-we-believed-in-a-questfor-justice).

Young Victoria, 2016 (13/07). Sydney's Indigenous communities are being forced out by gentrification, The Sydney Morning Herald (https://www. smh.com.au/opinion/sydneys-indigneous-communities-are-being-forced-out-by-gentrification20160713-gq4kwm.html).

Zноu Namman 2017 (5/03). Gentrification or marginalisation? Indigenous residents split over Redfern plan, The Guardian (https://www.theguardian.com/australia-news/2017/mar/05/ gentrification-v-marginalisation-indigenous-residents-split-over-redfern-development).

Vanessa CASTEjon, PLÉIADE - EA 7338, Université Paris 13 
Clément Julien, 2014. Cultures physiques. Le rugby à Samoa, Paris, Éd. Rue d'Ulm, coll. Sciences sociales, 240 p., préface d'A. Berthoz.

Julien Clément a publié, en 2014, un ouvrage tiré d'une thèse soutenue en 2009, et intitulé "Cultures physiques. Le rugby à Samoa ".

L'ouvrage ne présente qu'une partie des résultats d'un travail de recherche mené dans le cadre d'un master et d'un doctorat

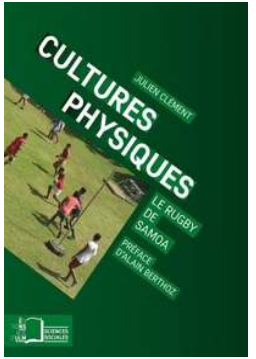
d'anthropologie (Clément, 2009). Il s'organise en sept chapitres dont on peut regretter que seuls les quatre derniers (La socialisation au rugby, Le travail des corps, Rencontres et Techniques du corps samoanes) traitent le cœur du sujet, à savoir les interrogations suivantes «Comment la culture passe-t-elle sous la peau ?Ou plus exactement, comment la culture entre-t-elle dans le corps et comment les corps [leur usage et leurs mouvements] deviennent-ils culturels ?" (p. 11). "La culture » est ici la culture samoanne. Les trois premières sections (Samoa et le rugby, Qu'est-ce qu'une équipe nationale?, La "Force du village " et les clubs) présentent le contexte socio-culturel et institutionnel.

La visée de ce livre dépasse donc ce qui tombe généralement dans le cadre de la sociologie du sport. Il croise, dans un style vivant émaillé d'exemples et d'anecdotes significatives, trois types de préoccupations : 1) le rapport corporel aux choses et l'approche phénoménologique permettant de le comprendre; 2) les techniques du corps et la capacité de ce dernier à agir dans un univers social donné ; 3) la complexité des phénomènes sociaux en perpétuelle mutation au sein d'un monde globalisé où les compétitions internationales de rugby présentent de nettes dimensions politiques (notamment la réification des identités nationales) en accord avec des principes commerciaux proposant un spectacle total où la diversité de l'offre est favorisée, bien que calibrée. Par ce croisement, l'auteur cherche à dégager la « résonnance » du geste dans le contexte culturel samoan, mais aussi la place du sujet dans un monde objectifié. Il en vient à expliquer les caractéristiques particulières du rugby samoan face à ce qui se pratique en France d'une part, et en Nouvelle-Zélande d'autre part, école sur laquelle s'appuient les préconisations de la Fédération internationale de rugby en matière de formation et d'entrânement. Cette particularité puise essentiellement dans l'" hybridité " du rugby samoan, à l'interface d'une culture polynésienne et des normes mondialisées.

Au principe de cette recherche fondée sur l'observation participante, un constat ${ }^{1}$ :

" [...] Lors du premier match que j'ai observé à Samoa, j'ai sursauté. Les situations de surnombre offensif, en particulier les « deux-contre-un », au cœur du rugby français, n'étaient pas joués par les Samoans de la manière à laquelle j'étais habitué en France. À l'inverse, les situations de " uncontre-un " étaient investies de façon spectaculaire et très efficace [...] À Samoa, par les plaquages, les appuis, les feintes, c'étaient les oppositions individuelles qui constituaient le lieu de l'action. Elles étaient au centre du jeu. " (p. 21)

Ainsi, le jeu des Samoans (celui notamment de l'équipe nationale) est-il

«très spectaculaire, fait d'une technique individuelle très efficace, d'une vivacité d'appuis surprenante et d'une rapidité de course qui permet de prendre de vitesse leurs adversaires. " (pp. 27-28)

« Il y a là un point de densité, poursuit l'auteur, dans ces plaquages, dans ces passes qui m’ont paru d'emblée très spécifiques par rapport au jeu européen [...], mais aussi dans l'entrainement, les discours de motivation, officiels et privés, les structures - tous ces éléments socioculturels qui sont impliqués dans le jeu et qui restent opaques [aux étrangers]. " (p. 28)

Dans un premier temps, l'auteur procède donc en croisant deux axes : 1) une présentation des institutions sportives à différents niveaux d'organisation (nation, district, village) ; 2) la description de l'engagement des garçons dans des réseaux de sociabilité imbriqués (école, famille, aumāga, obligations professionnelles, club sportif...) dont le rugby est seulement un des aspects.

Lanalyse s'intéresse particulièrement aux pratiques techniques (préparation physique, entrainement, jeu "à toucher " et matchs) et aux formes de continuité dans la mobilisation des techniques du corps que le modèle samoan favorise. Ces pratiques sont donc mises en relation avec la construction de collectifs à trois niveaux. Le premier niveau est celui de l'équipe nationale, dont la composition reflète l'atunu'u, la nation dans son organisation politico-coutumière spécifique et ses valeurs essentielles, mais aussi, dans son expression virile et guerrière ${ }^{2}$. Le deuxième niveau est celui que forme, pour chaque village,

«le groupe des hommes non chefs [aumäga, qui] fournit les éléments fondateurs des rapports sociaux et de l'embodiment des jeunes hommes, et donc des joueurs de rugby. " (p. 21)

Or, ces joueurs - et leurs villages - «sont pris dans une double perspective, de carrière sportive et d'honneur villageois " (p. 23). Tout d'abord, les joueurs sont sommés de "protéger le nom " de leur village d'origine $^{3}$. Dans ce cadre, ils incarnent pleinement « la Force du village " (o le Mälosi o le nu'u) et trouvent là un cadre de socialisation en dépit des mutations sociales qui imposent à certains un travail salarié. Ils restent ainsi soumis tant aux représentations communes relatives à la masculinité selon lesquelles le corps des jeunes hommes est « le lieu d'inscription de leur identité » (p. 42), qu’à

1. Le terrain, multisitué (plus de quatorze mois en totalité), a été effectué entre 2001 et 2010 au fil de cinq séjours.

2. Le nom (Manu Samoa) de l'équipe nationale fait référence à la valeur guerrière des hommes de Samoa.

3. C'est le cas, notamment dans les « matchs du bouclier " où le vainqueur remet chaque semaine son titre en jeu. 
la place et aux tâches assignées par leur communauté, mobilisant leur force physique au service des chefs, "atua [dieux] d'ici-bas " (pp. 73-74), à tout le moins, au service de l'honneur du village. Le lien de l'équipe et des villageois est donc étroit. Il est aussi réciproque. Les chefs participent au fonctionnement du club et se déplacent avec l'équipe pour assurer son fonctionnement dans le cadre des règles de la "coutume" (agānu'u, p. 145). Lors des matchs, chefs et villageois soutiennent l'effort, entrant collectivement en état de «spiritualité partagée » tapuåi (p. 141).

Le troisième niveau est celui de la scolarité et du système éducatif, formel et informel, qui donne au rugby une place importante. À ce niveau, les pratiques sont hétérogènes et offrent des formes de socialisation au rugby qui s'avèrent fondatrices: d'un côté, les pratiques formelles, au fil de la scolarité et des compétitions, où les règles de la préparation, de l'entrainement et du jeu suivent des normes internationales; d'un autre côté, les innombrables occasions informelles de jeu avec les camarades ou des aînés, lors des " jeux à toucher " (p. 109). Là, les jeunes gens sont rejoints par des joueurs de toutes générations, chacun s'essaye progressivement à des actions d'éclat sous le regard amusé ou admiratif du groupe. Ces moments sont marqués par les

" rires et les morceaux de bravoure de ceux qui n'en ont plus l'âge, comme de ceux qui veulent (se) prouver que l'avenir leur appartient [...]» (p. 110)

Certes, à Samoa comme ailleurs le "paradigme médico-sportif " "détermine la production des corps " (p. 119) au sein des institutions soutenues par les fédérations (nationale, internationale) et intégrées dans une économie capitaliste mondialisée. C'est donc dans les pratiques informelles du rugby et par leur intégration dans l'aumãga (ou l'adhésion à ses valeurs: sens de l'honneur, force virile, combativité) que les joueurs acquièrent, dès l'enfance, les qualités particulières qui distinguent le rugby samoan : la force physique et le goût de l'affrontement, la polyvalence et la quête du coup d'éclat, entre autres caractéristiques développées dans le cadre de la socialisation villageoise. Un espace de liberté y est offert à chacun pour expérimenter et améliorer ses aptitudes en contexte, donc pour s'y rendre utile et s'y faire valoir, car

« il y a un lien entre les différentes manières dont on s'entraine aux efforts dans le rugby et des conceptions sociales plus larges diffusées dans la société. » (p. 114)

Ces considérations apparaissent comme les préliminaires au chapitre final, où le cœur de l'action sportive est disséqué et analysé et ouvre des " perspectives cognitives " qui ont " valeur d'hypothèses " (p. 153). Partant de l'étude de quelques situations caractéristiques, ce chapitre initie le lecteur non familier aux avancées récentes en psychomotricité et en neurosciences, à l'analyse fine du fonctionnement du cerveau et, avec lui, de tout le corps engagé dans l'action. Si l'ensemble du livre suscite l'intérêt, cette partie consacrée aux techniques du corps centrales dans le rugby samoan, à savoir le plaquage samoan (au torse) et ses réponses (feintes et appuis), est certainement la plus originale. Au fil des analyses, le lecteur comprend que le premier

" apparaît comme une capacité à se placer dans un repère hétérocentré où le joueur adverse est rapidement pris dans l'espace corporel du plaqueur. » (p. 186)

Quant aux feintes et aux appuis, ils « jouent sur la capacité à dissocier les mécanismes de génération des trajectoires locomotrices par le cerveau " (idem), ce qui trompe les attentes de l'adversaire. Ainsi, les joueurs samoans se montrent-ils très offensifs dans les tournois internationaux, et leur jeu est-il souvent déroutant pour un adversaire non préparé. En revanche, on comprend pourquoi les situations de surnombre sont rarement exploitées par les Samoans et où se situe leur principale faiblesse, tout au moins pour les moins attentifs ou les moins expérimentés...

Cette lecture donne donc le sentiment que ce sont bien les valeurs de l'aumäga et des techniques du corps proprement locales qui, tant sur place que dans les confrontations internationales, donnent sa spécificité au rugby samoan. Pour l'auteur, ces pratiques et les situations que les joueurs rencontrent ont toutefois un caractère hétérogène, ce qui le conduit à l'hypothèse d'un "corps propre complexe» (p. 190) évoluant au cours de la vie des personnes et des réactualisations $\mathrm{du}$ rapport à un monde culturel complexe et changeant. On ne peut que constater sur la base de ses analyses, la remarquable synthèse que les joueurs samoans savent produire, individuellement et collectivement, lors des matchs internationaux. $\mathrm{Si}$ «les rencontres sportives fournissent un point d'intersection entre les deux pôles du rugby de Samoa " (p. 188), il semble bien quau niveau des phénomènes psychomoteurs de l'embodiment, une intégration étroite ait lieu, les perceptions et les techniques acquises en contexte de socialisation villageoise primant, semble-t-il, dans les actions que les joueurs estiment comme décisives. En attendant de pouvoir lire le résultat des recherches complémentaires que l'auteur annonce à venir, on pourra se référer à trois publications (en français et en anglais) sur le sujet (cf. Clément, 2010, 2013 et 2014).

\section{RÉFÉRENCES CITÉES}

CLÉment Julien, 2009. Le rugby à Samoa : les techniques du corps entre fáaSāmoa et mondialisation du sport, Thèse d'anthropologie, credo, Maison Asie-Pacifique, Université Provence Aix-Marseille I (https://www.theses.fr/2009AIX10046).

—, 2010. Le rugby de Samoa : entre fảasāmoa et globalisation du sport, Journal des anthropologues 120121 (https://journals.openedition.org/jda/4226).

_, 2013. Les Manu Samoa, L'Homme 205, pp. 79-97 (https://journals.openedition.org/lhomme/24422) .

-, 2014. Participating in the Global Competition: Denaturalizing 'Flair' in Samoan Rugby, The contemporary pacific, pp. 369-387.

Sophie Chave-Dartoen, UMR 5319 cNRs Passages/Université de Bordeaux 
Serra Mallol Christophe, 2010. Nourritures, abondance et identité. Une socio-anthropologie de l'alimentation à Tahiti, Tahiti, Au vent des îles, coll. Bibliothèque océanienne, 545 p., couv. ill. en coul.

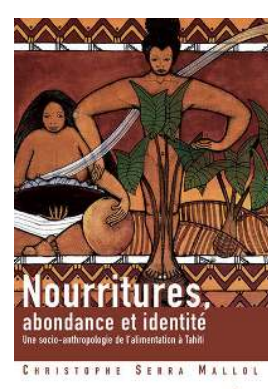

Christophe Serra Mallol draws on his fieldwork in two Tahitian communities early in the new millennium to place his ethnography of food ways across the time span from ancient Tahiti as recorded by European visitors in the 1600s up to modern Tahiti. The early visitors created a picture of Tahiti as a lush green environment in which food abounded; such depictions led to a misunderstanding that coined "the myth of abundance" (p. 220) which he questions. During their short-term stays botanists aboard these ships recorded the "bounty" of the vegetation of these isles as seen by European eyes. The author draws heavily on ethnographic detail provided by Teuira Henry and Morrison in particular for the picture of generosity that dominated Tahitians' cultural food ways; canoe loads of breadfruit, topped by a pig, gifted to visiting ships, such as Captain Cook's entourage in 1769, (Forster, 1777) were seen as emanating from a "paradise on earth", "a Garden of Eden (p. 223). A myth of abundance has persisted to present times as analysts by pen and film reconsider the Myth of the Bounty under Bligh's command - Fitzsimons (2018) among the latest.

But as Serra Mallol stresses, the myth of Tahiti as an "earthly paradise", a bounteous nature, one of the most fertile in the world, represents a misunderstanding of the realities of Tahitian food ways (p. 225). When the breadfruit season ended, Captain Cook found that in June 1769 local chiefs had imposed a rahui/ban on food gifts of taro etc, their only food, when the breadfruit season ended, so he could no longer replenish his ships. Abundance marked only part of the year's bounty on Tahiti; it was followed by a season of scarcity, until the breadfruit trees produced a new crop of fruit. Details of breadfruit and other plant foods on which ancient Tahitians relied are elaborated throughout the first 217 pages of this text; the author considers the main elements of what he terms Tahitians' edible space (p. 30), differentiating terrestrial resources, that have provided Tahitians with their main food base, from marine resources which provide an accompaniment to the starch foods (p. 45). Six plants, breadfruit, bananas, both fei /plantain, and sweet bananas, taro, yams, and coconut have provided the basic food resources (pp. 34-44), with occasional use of sweet potato and several fruits. Birds were caught occasionally, while fish from both oceans and lagoons provided an accompaniment, with coconut cream (miti) used as a sauce. Pigs contributed a significant symbolic and ceremonial addition to social life, but were not included in social terms as foods (e.g. p. 237).
The author stresses that since vegetable foods dominated 80 per cent of general fare, the food supply was dependent on the local ecology; plant and tree foods were limited and irregular in both timing and amounts, particularly during those periods of the year when there was no crop from breadfruit (p. 45). Animals that outsiders tried to introduce were repulsive to Tahitians (p. 242). All their vegetal foods were cooked in the earth oven. The author characterises the ancient Tahitian diet as tri-partite: $m a^{\prime} a$, ina'i, miti (starch, accompaniment and sauce (p. 109); that has persisted to mark Tahitian food identity to current thinking.

The myth of Tahiti as luxuriant and bountiful with an abundance of food (p. 222), a Garden of Eden, was created by European visitors, including, Joseph Banks botanist with James Cook's expedition (p. 176), and Teuira Henry and Samuel Morrison throughout the late 18th and early 19th centuries. But for Tahitians the reality was that the season of abundance (of breadfruit) was followed by five or six months of scarce food plant resources. Chiefs carefully controlled the limited supply with social restrictions, rahui, over distributions throughout communities, as suited environmental conditions. The myth carried back to Europe was based on "exotic" botanical specimens sold to European botanical gardens, but misrepresenting Tahitian food resources. The abundance (of breadfruits) which Tahitians cooked in large earth ovens and ate liberally when available, was castigated by missionaries as too easy according to the Protestant work ethnic, not requiring the hard work required for European crops, i.e. wheat, that marked a "civilised" life style (e.g. Ellis Polynesian Researches, 1829). These newcomers with their own views of "good food" began a downgrading of local foods that needed to be replaced by introduced i.e.European foods (Chapter 2).

Tahitians' own cultural values of foods and food ways were thus devalued, to be replaced by religious syncretism and technical innovations in the food scene (pp. 219-335). Bread made from imported flour replaced breadfruit as one example of how Tahitian food traditions have undergone subsequent amendments. The triple impact of Christianisation, the political and economic effects of French colonial production, and the aftermath of the installation in the 1960s of the nuclear testing centre (Centre d'expérimentation du Pacifique, CEP) all changed Tahitian attitudes to food.

On the basis of the "myth" of food abundance, paradoxical developments linked Tahiti to the wider food world throughout the 19th and 20th centuries. When Captain Bligh successfully transported a second shipment of breadfruit saplings from the Pacific to the Caribbean, he not only provided the latter's plantation owners with a desired new "easy" and abundant crop of cheap food (p. 239), - a practise that marked the beginning of many such food transfers into Tahiti, despite the local "abundance". New forms of food commerce in urban areas replaced traditions of food sharing, altered Tahitians' own eating patterns, as well as introducing others' higher valued imported 
foodstuffs, particularly bread (p. 239). The irony of contrasting images of abundance, yet devalued local food resources in favour of imported food ways is a highlight of this text.

The onslaught on Tahitian food values continued throughout the 19th century. Tahitians required cash to purchase the new expanded food inventory of imported foods. A new alimentary triad replaced the traditional Tahitian triad: bread as the starch, accompanied by butter, and coffee as the drink (café-painbeurre (p. 289) and consequent references). The three new foods had the merit of being quick to prepare, easily procured, and at minimum cost. But they also became monotonous, yet inevitable for those with little income. I.e those living on the outskirts of Papeete. While coconut plantations replaced breadfruit trees on the land, and copra from yielded some cash, particularly during the early 20th century, government and mercantile businesses provided limited employment for Tahitians drawn into a cash economy. Tahitians were transformed from subsistence eaters to become consumers (p. 297).

Major temporary employment opportunities, such as mining for phosphate at Makatea, the US military Base at Bora Bora during World War II, and associate with the establishment of the nuclear testing station at Mururoa in the 1960s (p. 310) had strong impacts on Tahitian food values and practices. For Tahitians, as the author argues, abundant food has become as illusory as the jobs needed to earn cash to buy it. The author questions why the myth of abundance has become so deeply entrenched as a characteristic of Tahitian identity even in modern times.

In the third section of the book, the author traces Tahitian modernity (pp. 337-523) by addressing the continuities afforded by ancient Tahitian and Polynesian cultural cuisine through to the early 21 st century. Findings from his own research in two Tahitian communities, Pamatai, outside Papeete, and Ma'atea, on the neighbouring island of Mo' orea, he draws a marked contrast between the latter community where ancient Tahitian values and practices, have persisted, albeit in modified form, and the sub-urban community of Pamatai who have of necessity become reliant on purchased, i.e. imported foodstuffs. Social consequences for considerations of abundance are marked.

For the Pamatai households cash purchases have become almost their only means of feeding their households, whereas Ma'atea households still rely on produce from their still verdant valley where the land still provides a subsistence life-style, with occasional purchases of tinned meats or frozen chicken for special occasions. Their diet is slightly more varied than their suburban cousins, for whom food choices have become more a matter of individual selections; Chinese plate lunches that workers regularly consume, consist of rice, meat sauce and a soda drink - thus replacing the traditional triad with modern foods. Cheap fast foods such as baguette and sodas are having health consequences for young and old Pamatai households. For those relatives who rejoin families on Mo'orea offering tra- ditional cuisine at Sunday lunches after Church, traditional tastes are kept alive. On these occasions extended family members, whether living and working on either island, are drawn together by the earth oven as the centrepiece for sharing produce from both the land and supermarkets. Plenty of food, laughter and goodwill provide the centrepiece for social interaction around traditional foodways. These two divergent forms of Tahitian foodways contribute to a new myth of abundance, associated with a new disequilibrium. Modifications of social access to food, including the meaning (and practices) of generosity, and new individual concerns about "good" food as healthy have emerged as a result of reinterpretations of Tahitian values over time. Serra Mallol's own research in the two communities highlights modernities that incorporate elements of Tahitians' own culinary cultural principles as practical in today's lifestyles. Abundance today may be occasional, co-existing with periods of scarcity for both communities. Tahitians "nourish" their social relationships with shared foods, as generosity remains a key social principle by which Tahitian identity is maintained. Abundance is a non-material assessment, that early European visitors misunderstood.

Serra Mallol concludes that food acculturation in Tahiti today is based on perpetuation of the social and cultural dimensions of food concepts and habits, not just functions and nutritional values (p. 528). Food is pleasuring within the social context today, as in the past, reinforced by daily rhythms no matter how little food is available - irregularity still contrasts times of abundance with times of scarcity in modern context (p. 528). Commensality and rituals in which food gifts are a prominent feature reinforce nourishing bonds. Traditional ways are reinterpreted in modern contexts. The myth of abundance is as much a social construct by outsiders, as it is one way of representing both past and present Tahitian foodways as Tahitians themselves consider them..

This valuable ethnography that collates material from a diversity of written sources as well as his own fieldwork to addresse continuities and changes in Tahitian food ways a is marred by several omissions, and difficulties in the labelling of sections of the text. Notably for the reader there is confusion in the labelling between sections and chapters, and references are supplied in both foot notes and a "Bibliography of principal works, articles and documents cited" (pp. 533-539).

The main arguments are presented in three sections as set out in the Summary (Sommaire) at the beginning of the book (pp. 6-10): the first section, entitled "Ancient Tahitian Food" (L'alimentation ancienne à Tahiti) (pp. 6-218) while the second section is entitled "The Opening to the other and new products (Louverture sur l'autre et ses nouveaux produits, pp. 219-336); the third section is entitled the outcome for "Tahitian modernity- a social-anthropological account of food" (pp. 337-532). However confusion arises for the reader between the untitled yet detailed three Sections in the Sommaire (pp. 6-10) and the labelling 
of each left hand page of the text as "Chapitre" 1, 2 or 3. In the Sommaire each section's title is printed in larger font size, with sub-sections printed with a smaller font; this enables the reader to follow the progression of the author's ideas. But within the lengthy three sections at the top of the left hand page appears a label Chapters 1, 2 or 3, that distinguish what I have called sections. Furthermore the Conclusion (pp. 524532) is included under a Chapter 3 heading. Whether these lay-out mis-matches are due to print editing is a concern. Readers wishing to cross-reference ideas in the text have to rely on the three section titles (larger font size and at the head of each right hand page) or the sub-sections as entitled in the Sommaire.

The absence of a map, or any tables or illustrations (apart from the cover) detracts from accessibility to specific data, particularly when recognising unfamiliar foodstuffs, and in following changes over time between the two communities. A clear map early in the text, would provide a visible aid to the location of this study within Oceania and within French Polynesia. Whereas "Tahiti" may be a familiar term to some readers, that name is often used here and elsewhere, as synonymous with the Society Islands, or even the larger entity of French Polynesia. In this text the author is referring in most cases to the island of Tahiti, as distinct from its (close) neighbour Mo'orea; at times he uses it to refer to the several other islands known as Society Islands, or French Polynesia, as part of Polynesia. Maps of the islands of the wider entity of Society Islands, and of Tahiti and Mo'orea in particular, would clarify the author's distinction between the environments, referred to in early writings as well as in his own two major research sites.

Illustrations/photos or drawings, of the major food plants in their environments would help clarify the local resources, seen as exotic by some outsiders, within the Pacific island environment. Photos of food resources such as breadfruit taro, fe'i bananas etc abound in the tourist literature, and their usage for example in an earth oven would be helpful for non-tropics-centred readers. Aerial photos of the two communities would be helpful for a wide readership without being too specific as to location. Figures and Tables could help clarify details of the comparison between the two communities, as well as changes over time, as discussed in the third part of the text.

The author cites numerous texts he has drawn on for this work in both footnotes and a Bibliography. The pages of the Bibliography together with the Index, are headed on each left hand page as Annexes (pp. 533545) but not in the Sommaire at the beginning. The running footnotes amount to a total of 826 , the last on page 532. So the Bibliography (pp. 533-539) is a helpful reference guide to the main citations. Readers may prefer to have the numerous citations placed at the end of each of the three sections.

The Index (pp. 543-545) is very hard to use. It has been condensed into three pages, by use of a smaller font, and omission of any spaces between key words. The type face is also very light. It seems apparent that the publishers were trying to reduce the length of the book, 545 pages in total, but that is a false economy for readers. Dipping into this long text is not assisted by the compacted Index.

A lexicon of principal Tahitian words used in the text (pp. 540-541), with some alternative spellings, is useful to clarify Ma'ohi (Tahitian) terms as translated into French. It clarifies the use of "ai" or 'amu as Tahitian words for "to eat", as distinct from $m a^{a} a$ as the generic term for "food" in the restrictive sense of vegetable foods; ma'a in turn is distinguished from ina'i or accompaniments (p. 540), as distinct again from pota, the Tahitian term for all green vegetables, whether taro leaves, salad or cabbage. These fine linguistic distinctions are integral to the theme of the ethnography whereby Tahitians distinguish between key aspects of their food ways as distinct from key English food concepts. The lexicon is a useful compilation of key Tahitian concepts that the author uses throughout the text to underline Tahitians' concept of "feeding" social as well as biological relationships.

The term "Nourritures..." used in the title and throughout the text is intentionally multi-vocal, inclusive of the social/cosmological, biological and ecological aspects of food ways that "nourish" the society. The author uses the term "alimentation" to refer what I translate into English as food or foodstuffs, as distinct from the wider social considerations of Tahitian food usage in anthropological setting.

The author and the publisher Au Vent des Iles, based in Papeete, are to be commended for filling a large gap in the literature on changing food ways and values of food over time, in either English or French for a Pacific community. And the book adds considerably to recent literature on Tahiti. Using an anthropological approach to emphasise both the social and biological importance of food in social relationships in a specific island ecological context, the author and publishers have made a major contribution to the anthropology of food in both the local framework and in a wider global framework. It is to be hoped that the French text will become available in English for a wider readership - and that the author's papers will likewise reach a multi-lingual readership.

\section{Cited References}

ELLIS William, 1829. Polynesian Researches during a Residence of Nearly Six Years in the South Sea Islands, Londres, Fisher, Son \& Jackson, 2 vol. Traduit en français par Marie Sergueiew et Colette de Buyer-Mimeure sous le titre : $\grave{A}$ la recherche de la Polynésie d'autrefois, Paris, Société des Océanistes, 2014 (https://books.openedition.org/ sdo/1089).

Fitzsimons Peter, 2018. Mutiny on the Bounty, A saga of sex, sedition, mayhem and mutiny, and survival against extraordinary odds, Sidney, Australia Hachette Book Group.

FORSTER Johann Georg, 1777. A Voyage round the World in His Britannic Majesty's Sloop Resolution, 
Commanded by Capt. James Cook, B. White, London, 1777.

Dr. Nancy J. Pollock (Retired), Depts. of Anthropology and development Studies Victoria University Of Wellington, New Zealand

Sissons Jeffrey, 2014. The Polynesian iconoclasm. Religious revolution and the seasonality of power, $\mathrm{New}$ York, Berghahn, 160 p. ill., index.

The Polynesian iconoclasm est un livre court (160 pages), trop court en réalité tant le point de départ de l'auteur est prometteur. Jeffrey Sissons met en effet en évidence la relation entre les iconoclasmes qui accompagnèrent la christianisation de la Polynésie orientale au début du XIX ${ }^{e}$ siècle et les cycles rituels du calendrier préchrétien. À

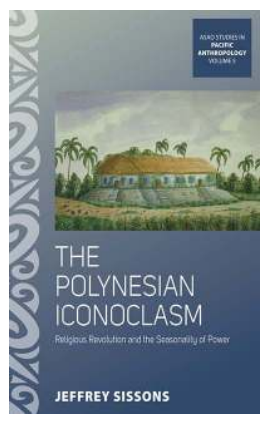

Hawai'i, aux îles Cook et dans les îles de la Société - cas le plus approfondi par l'auteur -, la transgression des tabous et la destruction des sites cérémoniels et des objets religieux se sont ainsi effectuées en conjonction avec l'alternance des saisons. Malheureusement, d'importantes imprécisions nuisent à la pertinence de son analyse.

Dans les îles de la Société, les deux saisons étaient nommées matari i $i$ nia et matarii i raro compte tenu de la position des Pléiades (matarii) dans le ciel. Mataríi i nia correspondait à la saison de la fructification (de mi-novembre à mi-mai) et matarìi $i$ raro à la saison plus sèche et plus fraiche (de mi-mai à mi-novembre). Dans la cosmologie des îles de la Société, l'alternance des saisons renvoyait à un cycle de régénération du monde et de la fertilité qui accompagnait le retour et le départ des divinités ancestrales (Babadzan, 1993 : 219-252). Pour Sissons, la christianisation se serait effectuée au rythme du cycle rituel accompagnant les saisons.

Il n'est donc pas surprenant que l'auteur débute son analyse en se référant à l'étude de Sahlins à propos de la mort du capitaine Cook (1985). Pour résumer la thèse de Sahlins, l'arrivée à Hawai'i du capitaine Cook aurait été appréhendée par les Hawiiiens à travers la venue saisonnière du dieu Lono. Le retour imprévu de Cook hors du cadre rituel dans lequel il s'était préalablement glissé aurait entrainé sa mort. Sahlins parle ainsi de mythopraxis, c'est-à-dire d'une improvisation se fondant sur les mythes. Le premier contact pour les Hawai'iens (pour les chefs et les prêtres en tout cas), aurait été appréhendé par le biais de la mythologie entourant Lono. Sissons préfere cependant parler de rituopraxis, qu'il définit comme l'improvisation à partir de référents rituels. Si ce néologisme est peu clair, il pose néanmoins une question essentielle : est-ce par rapport à leur relation au temps - à leur régime d'historicité (Hartog,
2003) - que les Polynésiens ont appréhendé les premiers contacts en tant qu'événement, ou par rapport à leurs divers moyens pratiques de constituer rituellement des relations d'altérité ? L'auteur ne développe malheureusement pas ce point et, passée l'introduction, entreprend de décrire le cycle rituel en Polynésie orientale et démontre le lien entre l'alternance des saisons et les iconoclasmes qui accompagnèrent la conversion au christianisme dans les années 18101820 (chapitres 2, 3 et 4).

Ainsi, dans les îles de la Société, c'est durant l'exil de Pomare I à Moorea que le christianisme des missionnaires protestants de la London Missionary Society (LMS) connaît ses premiers succès. Les nouveaux convertis commencent par transgresser publiquement les tabous de nourriture. Mais c'est suite à l'iconoclasme initial de Pati'i, en février 1815, que cette pratique se répand dans toute l'île de Moorea, de district en district. Or, comme le montre Sissons dans le cas de Moorea, puis des autres îles de l'archipel de la Société, mais aussi à Hawaỉi et aux îles Cook, ces iconoclasmes et ces transgressions de tabous ont généralement eu lieu selon une même temporalité saisonnière correspondant au cycle rituel préchrétien.

Dans une seconde partie, l'auteur éclaire la logique d'instauration du christianisme, en concordance avec ce cycle, en étudiant les nouvelles matérialités religieuses qui font écho aux iconoclasmes : l'inauguration des premiers temples protestants (chap. 5) et l'installation d'une presse pour imprimer la Bible en tahitien (chap. 6). Il considère également avec justesse que les résistances au christianisme sont, elles aussi, apparues publiquement en lien avec le cycle rituel préchrétien (chap. 7). Cette seconde partie sur l'instauration du christianisme se révèle être la plus intéressante de l'ouvrage, en particulier car c'est celle qui souffre le moins des graves lacunes sur lesquelles se fonde autrement l'analyse de l'auteur à propos de la saisonnalité du pouvoir.

À partir de l'analyse de Sahlins qui considère les rites du Makahiki comme une période de communitas, l'auteur étend ce principe dans le temps et dans l'espace. Ainsi, il considère qu'à Tahiti, la saison de matarii i nia (à partir de fin novembre) aurait été associée à la communitas, alors que durant celle de matarii i $i$ raro (dès la fin de mai) auraient prévalu les rituels hiérarchiques de légitimation des chefferies. L'auteur ne détaille en aucune manière ce qui lui permet d'identifier ce dualisme, qui, selon lui, se retrouve également au cours de la christianisation comme le passage d'un temps de la communitas à un temps d'ordre social.

Cependant, trois points mettent fortement en doute ce dualisme. Tout d'abord, l'auteur fait du pa'iatua le rituel exclusif de l'entrée dans matarìi $i$ raro (vers mai-juin) lors duquel sont réaffirmés les pouvoirs des ariż. Le påiatua était une cérémonie liée au culte du dieu 'Oro au cours de laquelle les plumes rouges nécessaires à la plupart des actions rituelles étaient retirées des to’o (des effigies anthropomorphes 
en sparterie) dont elles sortaient "rechargées ", alors que d'autres plumes y étaient insérées à leur tour. Certes, ce rituel peut être perçu comme un rituel hiérarchique au sens où l'arii possédant les effigies les plus importantes - celles de 'Oro - se trouvait au cœur du système de concentration/redistribution des moyens d'actions rituelles. Cependant, rien ne permet d'affirmer, comme le fait l'auteur, que le pa'iatua était l'apanage des cérémonies d'entrée dans matarii $i$ raro. Sissons écrit ainsi :

"The LMS authors do not say when this rite was performed but this was almost certainly in May or June. " (2014: 21)

Mais bien au contraire, les principales sources concernant ce rituel, que l'auteur cite pourtant, le font explicitement intervenir quatre fois par an (Moerenhout, 1837, I : 514-515; Ellis, 1972, I, : 195). Teuira Henry, quant à elle, l'associe à des occasions particulières (consécration d'un souverain, maladie, fondation d'un marae, calamités [Henry, 2004 : 165]). Les documents historiques peuvent bien évidemment être critiqués, mais encore faut-il mentionner comment et pourquoi on les remet en cause, ce que l'auteur omet tout à fait ici.

Deuxièmement, cette caractérisation du cycle rituel entre communitas et hiérarchie est également remise en cause par des témoignages directs. En effet, dans le cas de Tahiti, la principale description qui nous soit parvenue d'une cérémonie d'investiture d'un grand chef, rituel « hiérarchique " s'il en est, est celui de Tu (le futur Pomare I), qui a eu lieu le 14 février 1792 (Morrison, 1966 : 85-86) et dont les préparatifs s'étalèrent sur toute la période pourtant identifiée par l'auteur comme celle de la communitas, c'est-àdire, selon lui, de la remise en cause ritualisée du pouvoir hiérarchique.

Il est enfin permis de s'interroger sur l'absence de référence aux arioi dans un livre qui donne tant d'importance aux cycles rituels de régénération et fertilité, alors qu'ils étaient directement associés à 'Oro. Ce sont les actes des 'arioi qui rappellent aux chefs qu'ils ne sont pas des dieux, mais cette balance est symbolique et participe de la routine du rituel en confortant finalement les arii dans leur position d'intermédiaires entre les hommes et les dieux. On peut d'ailleurs se demander si la clé des iconoclasmes, dans les îles de la Société, n'est pas aussi à associer aux processions saisonnières et transgressives des 'arioi.

La proximité culturelle des différents archipels polynésiens offre la tentation d'en tirer des comparatismes généralistes. Si le cycle rituel saisonnier à Hawai'i semble aussi proche de celui des îles de la Société que le suggère son nom (MakahikilMatari'i), une différence cruciale existe pourtant, car le dualisme communitas/hiérarchie identifié par Sahlins à Hawai' i semble davantage tenir de la dualité à Tahiti :

"Les pouvoirs religieux des 'Arioi fondés sur la possession et l'initiation, et les pouvoirs politiques du roi dévolus par primogéniture, se rapportent donc à deux fonctions non seulement distinctes mais opposées dans les représentations tahitiennes : guerre versus fertilité. Dans toute la
Polynésie (sauf à Tahiti) ces deux fonctions avaient chacune une divinité tutélaire : Rongo et Lono prenaient en charge la promotion de la fertilité et l'agriculture chez les Maoris et à Hawai'i respectivement ; Ku et Tu, la guerre. Aux îles de la Société, à l'évidence, 'Oro était la divinité de la fertilité et de la guerre. Cette singularité majeure de la religion tahitienne est jusqu’à présent restée inexpliquée. " (Babadzan, 1993: 303)

La principale faiblesse de cet ouvrage est donc de reproduire la grille d'analyse proposée par Sahlins concernant Hawai'i, plutôt que de resituer la question des cycles rituels dans une étude précise de l'histoire des îles de la Société lors des premiers contacts et de la christianisation. Si la christianisation s'est effectuée à un rythme comparable au cycle rituel préchrétien, la saisonnalité du pouvoir que l'auteur y associe n'est pas mise en évidence par les documents historiques. Elle est imposée a priori par transposition du cas Hawai'ien.

\section{RÉFÉRENCES CITÉES}

Babadzan Alain, 1993. Les dépouilles des dieux, Paris, éditions de la MSH.

ELLIs William, 1972. À la recherche de la Polynésie d'autrefois, Paris, Société des Océanistes, Publications de la Société des Océanistes 25 (https:// books.openedition.org/sdo/1088 et https://books. openedition.org/sdo/666).

Hartog François, 2003. Régimes d'historicité : présentisme et expérience du temps, Paris, Seuil.

Henry Teuira, 2004 [1928]. Tahiti aux temps anciens, Paris, Société des Océanistes, Publications de la Société des Océanistes 1 (https://books.openedition.org/sdo/1402?lang=fr).

Moerenhout Jacques-Antoine, 1837. Voyages aux îles du Grand Océan, Paris, A. Bertrand.

Morrison James, 1966. Journal de James Morrison, second maître à bord de la "Bounty " Paris, Société des Océanistes, Publications de la Société des Océanistes 16 (https://books.openedition.org/ sdo/159).

Sahlins, Marshall, 1985, Islands of History, Chicago, University of Chicago Press.

Guillaume AlEVÊQue

Gnecchi-Ruscone Elisabetta and Anna Paini (eds), 2017. Tides of Innovation in Oceania. Value, materiality and place, Canberra, ANU Press, $347 \mathrm{p}$. (http://press-files.anu.edu.au/downloads/press/ n2395/pdf/book.pdf?referer=2395).

Résultat d'un projet initié lors de la conférence de l'European Society for Oceania à Vérone en 2008, l'ouvrage Tides of innovation in Oceania est paru en 2017. Sa force réside dans une certaine familiarité des

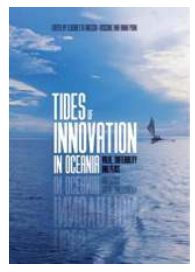


exemples choisis par les contributeurs. Ces derniers interrogent, selon leur terrain (Nouvelle-Calédonie, Vanuatu, Fidji, Nouvelle-Guinée) et leur objet d'étude (formes de l'autorité, musées, alimentation, tourisme, échanges), les processus de "continuité, transformation et récurrence » (p. 28) mis en œuvre par les habitants du Pacifique pour faire face à ces " marées d'innovation " qu'ils ont eu à négocier, du peuplement des îles à nos jours.

Létranger-roi dans le monde austronésien (chapitre 1), les collections réunies lors des voyages de Cook (chapitre 2), les bambous gravés (chapitre 3 ) et les robes mission (chapitre 4) de Nouvelle-Calédonie, l'échange des porcs en Nouvelle-Guinée (chapitre 6), la consommation de sodas et d'autres biens importés dans le Pacifique (chapitre 8), les attractions touristiques phares que sont le Saut du Gol au Vanuatu (chapitre 7) ou la marche sur le feu à Fidji (chapitre 9) invitent ici, de façon pertinente, à remettre en perspective les notions de tradition et d'authenticité au cœur des débats anthropologiques contemporains.

Louvrage s'efforce de revenir sur l'impasse, amplement discutée dans les années 1980 et 1990 (voir par exemple Kirshenblatt-Gimblett, 1998 ; Hau'ofa, 1993 ; Sahlins, 1985), qui consisterait à considérer les cultures comme isolées, fragmentées, détachées des processus historiques et relationnels qui les nourrissent, reflets d'une version idéalisée et largement imaginée du passé (Hobsbawm and Ranger, 1992). En réaction, les éditrices ont choisi pour le titre du volume le terme d'innovation, connoté positivement, et l'image du flux et du reflux, éloquente en contexte insulaire. Les contributeurs corrèlent ces "marées d'innovation" à des paramètres globaux, mais en analysent les conséquences au niveau local.

Cette tension entre global et local est au cour de l'ouvrage. On regrettera donc qu'elle ne soit pas davantage interrogée en introduction. Une introduction qui, par ailleurs, aborde aussi très peu la notion même d'innovation et celle, complémentaire, de tradition. Elisabetta Gnecchi-Ruscone et Anna Paini se lancent à la place, et avec un succès mitigé, dans la tâche colossale de contextualiser au sein de la discipline anthropologique les notions de valeur, de matérialité et de lieu (place) qui forment le soustitre de l'ouvrage et, selon les éditrices, l'ossature des communications rassemblées. Qu'en est-il dans ce cas du pouvoir d'action, de l'agency des populations océaniennes, également présente dans tous les textes et centrale dans les débats anthropologiques de ces vingt dernières années? Elle n'est, elle aussi, qu'effleurée. C'est pourtant là, à mon sens, que les éditrices sont les plus efficaces; quand elles traitent de ce pouvoir d'action qu'ont différents acteurs en termes d'innovation, d'adaptation et de régénération culturelle et qu'elles reviennent à l'idée éponyme du panel de la conférence de Vérone, "putting people first ». Il s'agit bien, là, de se placer du côté indigène de l'histoire et de contribuer à une décolonisation des études océaniennes, engagée il y a déjà plusieurs décennies (voir par exemple Howe et al., 1994 ; Tuhiwai Smith, 1999).

L'introduction est heureusement complétée par deux autres textes, un " prologue " et un " épilogue ", respectivement écrits par Andrew Motu et Christian Kaufmann. Tous deux reviennent sur la genèse du projet et son évolution. Tous deux interrogent aussi d'autres traditions et nécessaires innovations, au sein de la discipline anthropologique. Au centre de la discussion, le rôle des anthropologues, leur formation, leurs méthodes, leurs objectifs et leurs filiations avec la période coloniale. Il est surtout question de la pertinence de la discipline sur le long terme; et pour qui. Ces thèmes apparaissent aussi en filigrane dans la plupart des chapitres, notamment ceux de M. Jolly, S. Kuehling, N. Pollock, M. Tabani et G. Pigliasco.

Le corps de l'ouvrage consiste en neuf chapitres, répartis en deux parties: "Mapping Materiality in Time and Place" et "Value and Agency: Local Experiences in Expanded Narratives». Les chapitres de la première partie analysent la capacité des populations océaniennes à intégrer le paramètre étranger dans leurs stratégies de développement au long cours. Ils combinent habilement profondeur historique et préoccupations autochtones contemporaines et soulignent le rôle clé de la culture matérielle et des hiérarchies de pouvoir dans cet accord entre passé et présent. La seconde partie reprend l'idée de profondeur historique, mais s'articule davantage autour de la dialectique local/global. Elle éclaire ainsi les résonances et les dissonances qui existent entre les sociétés océaniennes et la communauté internationale, par exemple en termes de propriété. Politisation et marchandisation sont, ici, les maittres-mots de cette deuxième partie de l'ouvrage.

Marshall Sahlins inaugure la première partie avec un texte comme lui seul sait les écrire. Il y reprend ses thèmes de prédilection, celui de «l'étranger-roi » et du composant étranger comme source de pouvoir en Océanie. Il explicite l'idée d'une altérité menaçante et bénéfique à la fois, telle qu'elle est sans cesse réitérée et renégociée dans le monde austronésien. Une excellente entrée en matière qui fournit des points de compréhension historiques et cosmogoniques importants pour mieux appréhender les chapitres suivants. Le texte de M. Sahlins trouve, par exemple, un écho particulier dans l'idée évoquée par Margaret Jolly (chapitre 2) de présenter Tupaia et Cook comme des figures ancestrales du Pacifique (p. 100) lors de l'exposition des collections Forster à Canberra en 2006. Dans le second chapitre, Margaret Jolly compare en effet la façon dont les collections Forster de l'Université de Göttingen (réunies lors du second voyage de Cook) furent présentées à Honolulu puis à Canberra. Elle analyse les différences muséographiques, compare la manière dont ces expositions ont présenté la figure ambivalente de Cook ainsi que la violence des « contacts " entre les populations océaniennes et les marins européens. Son étude prend également en compte les discours et les réactions suscitées par chacune des expositions $-\mathrm{y}$ compris auprès des visi- 
teurs et des chercheurs autochtones - et s'attache à la question du « retour au pays » des objets. M. Jolly s'intéresse en outre aux omissions et aux manifestations associées à chaque exposition. Finalement, elle nous rappelle que, malgré de bonnes intentions, «le projet de créer des musées et des galeries d'un genre "nouveau" qui réaliseraient les aspirations postcoloniales et respecteraient véritablement les liens vitaux entre les créations océaniennes ancestrales et leurs descendants vivants " est loin d'être atteint (p. 104).

Les changements en cours dans les dynamiques de pouvoir entre les communautés autochtones et les musées sont aussi évoqués par Roberta Colombo Dougoud (chapitre 3). L'auteure s'appuie sur l'exemple des bambous gravés de Nouvelle-Calédonie conservés au musée d'ethnographie de Genève et sur le travail de l'artiste kanak Micheline Néporon pour aborder les liens qui existent, dans les arts océaniens, entre techniques du passé, affirmation identitaire contemporaine et contribution aux enjeux de société de chaque époque.

Il est encore question de culture matérielle, d'altérité et d'autochtonie dans le texte d'Anna Paini (chapitre 4), le deuxième de trois chapitres consacrés à la Nouvelle-Calédonie et plus particulièrement au pouvoir d'action des femmes kanak. À partir de données recueillies sur le terrain depuis les années 1980, Anna Paini explore le rôle des robes dites " mission " dans l'affirmation identitaire et l'émancipation des femmes kanak. Ce faisant, elle ajoute à la problématique de ces revendications des distinctions importantes, par exemple entre milieu urbain et rural, ou bien encore entre communautés protestantes et catholiques. En détaillant l'évolution matérielle et symbolique d'un objet "colonial devenu culturel " (p. 141), A. Paini recadre habilement les préoccupations d'authenticité qui ouvrent son récit et ponctuent l'ensemble du volume.

Les notes de Marie-Claire Beboko-Beccalossi (chapitre 5), publiées de façon posthume, font la transition vers la seconde partie. Elles reprennent le thème de l'affirmation et de l'émancipation des femmes kanak, cette fois sous un angle plus politique. Retraçant l'histoire de la représentation des femmes de Nouvelle-Calédonie dans l'espace public, le texte de M.-C. Beboko-Beccalossi souligne aussi un autre élément récurrent de Tides of innovation: l'importance et la difficulté de bien nommer les choses. Les changements d'appellation des assemblées de femmes, par exemple, reflètent la tension entre affranchissement et adaptation aux normes coloniales. Déjà présent dans les premiers chapitres, notamment le chapitre 4 , ce poids des mots et des formulations est examiné encore davantage par les auteurs de la seconde partie. S'ils continuent d'étudier l'interprétation des paradigmes océaniens dans le Pacifique et au-delà, ils réfléchissent surtout à la transformation des attentes océaniennes à l'aune de tendances globales : institutionnalisation des apprentissages (chapitre 6), développement et tourisme (chapitre 7), diversification alimentaire (chapitre 8) et législation sur la propriété intellectuelle (chapitre 9).

Susanne Kuehling (chapitre 6) explore spécifiquement le rôle du vocabulaire dans l'intégration de concepts venus de l'extérieur et la création de nouvelles dynamiques, sur l'île de Dobu (Papouasie Nouvelle-Guinée). L'accent est mis sur la capacité de mots que l'auteure qualifie "d'onéreux " (expensive) à marquer la transformation des usages et l'adaptation à de nouveaux besoins. Il s'agit par exemple d'obtenir de quoi payer, avec de l'argent, les frais de scolarité des enfants sans affaiblir les relations de parenté, basées sur des échanges non marchands. La solution, une truie nommée "skulfi " (school fee), que ce nom place distinctement dans la sphère des échanges monétarisés. Kuehling souligne aussi le renouvellement, dans un monde globalisé, des savoirs réservés qui sont source de prestige pour ceux qui les détiennent et se manifestent dans la région, notamment, par un vocabulaire spécialisé.

Marc Tabani (chapitre 7) revient sur le développement de l'industrie touristique au Vanuatu, en particulier sur l'île de Tanna, et sur ce qu'il qualifie de marchandisation voire de "prostitution " de la culture. Au-delà des facteurs exogènes, Tabani explore un enchevêtrement de stratégies politiques et commerciales locales et un paradoxe, celui d'une kastom perçue à la fois comme victime et rempart face aux travers de l'occidentalisation (p. 245).

Dans le chapitre 8, Nancy Pollock examine l'évolution de l'alimentation et du goût dans le Pacifique, du peuplement des îles à nos jours. L'analyse historique est particulièrement efficace et permet d'apporter de la nuance à certains clichés, qui opposent par exemple produits des jardins et denrées importées. La dimension morale des débats sur la biodiversité, l'équilibre et la sécurité alimentaire est placée en regard de la réalité océanienne. Pollock évoque ainsi la spécificité des environnements insulaires, la compétitivité de certains produits importés, les revers d'une grande abondance de choix et la transformation plutôt que l'abandon des marqueurs identitaires que l'on trouve, comme partout ailleurs, en cuisine.

Dans le $9^{\mathrm{e}}$ et dernier chapitre, Guido Carlo Pigliasco traite de l'inadéquation qui existe entre les notions de propriété telles qu'elles sont décrites et légiférées par la communauté internationale et la protection d'une identité culturelle qui se construit, par essence, au niveau local. À travers l'exemple des motifs de tapa revendiqués comme emblème de la compagnie aérienne Fiji Airways, Pigliasco souligne l'absence d'un langage commun et le manque d'outils adaptés à la protection de traits culturels (motifs, rituels) qui relèvent du collectif plus que de l'individu, et dont les Fidjiens se considèrent gardiens et usagers plutôt que créateurs ou propriétaires.

Sans surprise, les textes réunis dans Tides of innovation mettent l'accent sur le caractère continu des changements dans le Pacifique. Il est question d'adaptation, de résilience, de plasticité ou, pour reprendre la métaphore du titre, de fluidité, bien plus que de 
rupture ou de bouleversement. En cela, l'ouvrage se rapproche d'autres discours récents, sur le changement climatique par exemple (Farbotko and Lazrus, 2012). Cet ouvrage rassemble des approches et des thématiques déjà bien représentées dans la littérature sur le Pacifique, mais souvent traitées séparément (musées, culture matérielle, langage, propriété intellectuelle, tourisme, alimentation). Il favorise ainsi des comparaisons originales. Tides of innovation contribue à une discussion rendue incontournable par Epeli Hau'ofa (p. 9) et invite les lecteurs à penser toujours davantage en termes de flux plutôt qu'à partir d'éléments isolés. Finalement, l'ouvrage encourage la communauté anthropologique à explorer ses propres attachements au passé, à repenser son rôle de médiation entre global et local, et à faire preuve d'introspection dans sa propre crise identitaire.

\section{RÉFÉRENCES CITÉES :}

Farbotкo Carol and Heather Lazrus, 2012. The First Climate Refugees? Contesting Global Narratives of Climate Change in Tuvalu, Global Environmental Change 22 (2), pp. 382-390.

Hau'ofa Epeli, 1993. Our Sea of Islands, in A New Oceania: Rediscovering Our Sea of Islands, Suva, School of Social and Economic Development, The University of South Pacific, pp. 2-16.

Hobsbawm Eric and Terence O. Ranger (eds), 1992. The Invention of Tradition, Cambridge, Cambridge University Press.

Howe Kerry R., Robert C. Kiste and Brij V. LaL, 1994. Tides of History the Pacific Islands in the Twentieth Century, St Leonards, Allen and Unwin.

Kirshenblatt-Gimblett Barbara, 1998. Destination Culture: Tourism, Museums, and Heritage, Berkeley, University of California Press.

SAHuins Marshall, 1985. Islands of History, Chicago, University of Chicago Press.

Tuniwar Smith Linda, 1999. Decolonizing Methodologies: Research and Indigenous Peoples, London, Zed.

Stéphanie LeClerc-CaFfarel, Responsable de la collection Océanie Musée du quai Branly-Jacques Chirac

Brunt Peter et Nicholas Thomas (éds.), 2019. Océanie, Paris, Musée du quai Branly-Jacques Chirac / Fonds Mercator, 327 p., ill., cartes, bibliogr.

Publié à l'occasion de l'exposition débutée à la Royal Academy of Arts à l'automne 2018, ce catalogue est une traduction de l'original paru quelques mois plus tôt, alors même que l'exposition présentée au musée du quai Bran-
ly-Jacques Chirac jusqu'au 7 juillet 2019 est organisée sous une forme un peu différente et délestée de certains des objets prêtés par le British Museum. Les deux expositions sont présentées à l'occasion du $250^{\mathrm{e}}$ anniversaire du premier voyage du grand explorateur anglais James Cook dans le Pacifique.

Le catalogue suit donc de manière plus fidèle la première version de l'exposition que la seconde. Une fois passés les chapitres d'introduction et de contextualisation, les autres se déploient selon la disposition des six salles ou ensembles de salles de la Royal Academy of Arts auxquelles était dévolu un thème spécifique, aux accents tantôt historiques, tantôt anthropologiques: "Voyage et navigation ", "Créer le lieu ", "L'esprit du don », "Performance et cérémonie ", " Rencontre et empire ", " Mémoire ».

L'exposition - et donc le catalogue - a ceci de particulier qu'elle présente à la fois des objets parmi les plus anciens, qui datent souvent des premiers grands voyages européens et des œuvres d'artistes contemporains, particulièrement de Nouvelle-Zélande.

Comme le dit Noelle M. K. Y. Kahanu, conservatrice et artiste hawai' ienne, dans le chapitre 3 sur les collections et le don, "il est possible de considérer l'exposition "Oceania" sous un nouvel angle, comme une collection d'objets culturels significatifs et importants qui attestent l'éventail complet des rencontres pacifiques et européennes" ou encore "les œuvres exposées peuvent être considérées comme des représentations tangibles de rencontres entre habitants du Pacifique, le capitaine Cook et ceux qui ont suivi ses traces » (p. 69). La réflexion des quatre auteurs du chapitre est bien plus apaisée que ce que l'on entend parfois sur le pillage des régions découvertes et le lien entre les collections et le colonialisme. Il est en effet difficile de savoir comment les choses se sont réellement passées. Le don était-il vraiment volontaire ? Et ne serait-il pas irrespectueux vis-à-vis des décisions des ancêtres hawai' iens, par exemple, de demander la restitution d'objets précieux qui appartenaient à des chefs qui en ont fait cadeau aux explorateurs accostant sur leurs rivages?

Deux chapitres, le premier, rédigé par l'historienne néo-zélandaise Anne Salmond, et le quatrième, écrit par Michael Mel, originaire de Mount Hagen en Papouasie Nouvelle-Guinée et actuel responsable des collections du Pacifique à l'Australian Museum de Sydney, mettent l'accent sur des différences majeures entre les conceptions européennes et océaniennes de la mer, du corps et des relations aux autres. Anne Salmond rapporte un échange au cours duquel la notion de "propriété " liée à la réalité de l'océan apparaît dans la bouche de Tupaia, qui accompagna l'Endeavour, suite à une traduction inappropriée de Joseph Banks. En Polynésie, «la mer était conçue comme un site sacré, un vaste marae, et les îles comme des poissons tirés de l'océan " (p. 48). L'idée que les êtres humains puissent posséder la terre n'existait pas. Les Européens, quant à eux, traitaient la mer comme une "mare nullius, vaste espace désert attendant d'être "découvert", exploré et revendiqué par les nations eu- 
ropéennes " et, " sur leurs cartes, Cook et ses hommes abstrayaient et maillaient le Pacifique » (p. 50). La contribution très personnelle de Michael Mel, consacré au corps et à la performance, fait écho à ces visions contrastées, l'une où l'environnement est détaché des êtres humains et de leurs corps, l'autre où, lors d'une performance rituelle, "le corps fusionne avec une synergie de mouvements, couleurs, sons et odeurs, discrets mais inséparables " (p. 73).

Le chapitre 2, rédigé par Emmanuel Kasarherou, est consacré à la Nouvelle-Calédonie, assez peu représentée dans l'exposition. On y apprend l'importance de l'igname dans la subsistance ainsi que sa complémentarité symbolique avec le taro, associé au féminin, alors que l'igname est associé au masculin. La Grande Case est également l'objet d'un développement : sa structure architecturale est analysée et ses rapports avec l'organisation sociale et la chefferie soigneusement établis. Les trois photos prises au tournant du $\mathrm{Xx}^{\mathrm{e}}$ siècle font vivre ces éléments architecturaux et, sur l'une, les habitants ne semblent, pour une fois, pas trop poser pour l'appareil du photographe. L'introduction déroule méthodiquement les questions qui se posent à propos des collections rassemblées dans les musées européens, résultats de dons et d'échanges, mais aussi de pillages. Avec la distance que permet le recul du temps, " la collecte des objets a été pratiquée en telle quantité, à de si nombreuses fins, par tant de personnes différentes et dans des circonstances si particulières que toute généralisation à propos de ce phénomène est périlleuse » (p. 22). « La plupart des objets reflètent les modernités complexes des rencontres des peuples autochtones avec l'Occident » (p. 23). Ces rencontres ont été tumultueuses, souvent violentes et cette " "tempête" d'expansion et de modernité coloniales sous-tend l'exposition, dont elle conditionne la possibilité » (p. 31).

L'exposition n'est pas, comme beaucoup d'autres, organisée en divisions régionales et chacun des espaces mêle donc des objets provenant de ce que l'on appelle, depuis que l'explorateur français Dumont d'Urville a proposé cette classification, la Mélanésie, la Polynésie et la Micronésie. Ici, l'organisation est autre et se focalise sur l'eau, principalement sous sa forme "océan" (moana), avec trois thèmes enchevêtrés abordés dans leurs résonances réciproques : le voyage, la création d'espaces et la rencontre (p. 31).

Les objets anciens exposés sont, dans leur très grande majorité, exceptionnels, et leur association avec à la fois des œuvres d'artistes contemporains du Pacifique et des objets où la marque des rencontres avec le monde occidental est tangible via les motifs représentés (Églises, bateaux occidentaux, armes) ou les matériaux utilisés (tissus européens) les inscrit dans une continuité qui évite de les considérer comme des objets fossiles, témoins d'une époque totalement révolue. À la fin du catalogue, chaque objet donne lieu à une minutieuse description et à des explications sur son usage et sa signification qui sont particulièrement bienvenues.

On ne pourra s'empêcher de comparer ce catalogue avec un ouvrage volumineux paru six ans plus tôt en anglais des mêmes auteurs, assistés des plus grands spécialistes de l'art océanien (Brunt et Thomas, 2012). Art in Oceania: A new History est plus riche en thématiques et en textes et sans doute moins en illustrations, mais c'est vers lui qu'il faudra se tourner si l'on veut des analyses fouillées sur chacune des périodes concernées, depuis l'art de la préhistoire jusqu'aux ouvres d'aujourd'hui. Indépendamment du fait que le premier paru n'est pas traduit en français, les deux ouvrages sont finalement plus complémentaires que comparables. En aucun cas, ils ne devraient se faire concurrence.

\section{RÉFÉRENCES CITÉES :}

Benjamin Walter, 1942. Walter Benjamin zum Gedächtnis/In memory of Walter Benjamin, Los Angeles, Institut für Sozialwissenschaft (éd. fr. 2013 : Sur le concept d'histoire. Suivi de Eduard Fuchs, le collectionneur et l'historien; et de Paris, la capitale $d u X I X$ siècle, Paris, Payot et Rivages).

Brunt Peter and Nicholas Thomas (eds), 2012. Art in Oceania: A new History, London, Thames and Hudson.

Pascale Bonnemère, Aix-Marseille Université-CNRS-EHESS, CREDO,

1. Le terme «tempest » a été repris par l'ensemble artistique mau fondé par le chorégraphe samoan pour qualifier une production présentée en 2010 à Edimbourg. Il provient des thèses écrites en 1940 par Walter Benjamin sur la philosophie de l'histoire ("Über den Begriff der Geschichte »/« Theses on the Philosophy of History », $1^{\text {re }}$ éd. 1942). 